Сергій Бурий
Військовий інститут Київського національного університету
iмені Тараса Шевченка
ORCID ID 0000-0001-8058-5018

\title{
ПЕДАГОГІЧНІ УМОВИ ФОРМУВАННЯ УПРАВЛІНСЬКОЇ КУЛЬТУРИ У МАЙБУТНІХ ОФІЦЕРІВ В ПРОЦЕСІ ПРАКТИЧНОЇ ПІДГОТОВКИ
}

\begin{abstract}
У статті розглянуто наукові дослідження щзодо теорії значення рушійних сил $i$ діяльнісного прочесу в системі освіти та їх практичне значення при формуванні знань, навичок та вмінь з управлінської культури майбутніх офімерів. Розкриваються та науково обтрунтовуються педагогічні умови, які визначають забезпечення якісної професійної підготовки майбутніх офіџерів, а саме: організаційні, методичні, психологопедагогічні. Педагогічні умови в освітньому процесі управлінської підготовки військових становлять основу у формуванні високого військового професіоналізму, який має складовими: систему професійних знань і вмінь з управління підрозділом, навчання та виховання підлеглого особового складу; систему поведінкових якостей; систему морально-психологічних якостей. Теоретично обгрунтовуюється управлінська культура офіцера та ї̈ практичне значення для офіцера при виконанні ним сочіально значимих професійних обов'язків.
\end{abstract}

Ключові слова: управлінська культура офіцера; педагогічні умови; управлінська підготовка у вищих військових навчальних закладах.

Постановка проблеми. Розробка педагогічних умов формування управлінської культури в процесі професійної підготовки майбутніх офіцерів. Проведення науково-практичного аналізу літературних джерел щодо теоретичного та практичного значення педагогічних умов для розвитку освітнього процесу вищого військового навчального закладу (далі ВВН3) відповідно до світових стандартів підготовки військовослужбовців.

Випускники в процесі управлінської підготовки - це офіцери тактичного рівня, які здобули достатні знання та розуміння процесів планування, ведення і забезпечення бою загальновійськовим підрозділом (тактичною групою). Здобуті знання та розуміння дозволять їм приймати обгрунтовані рішення в бойових умовах, вирішувати нетипові завдання, віддавати накази (розпорядження), нести відповідальність за їх виконання.

Аналіз останніх досліджень і публікацій. У педагогічній науці аналізуються й обгрунтовуються значення рушійних сил навчального процесу для ефективного опанування навчального матеріалу такими науковцями: М.А. Данілов, В.І. Загвязінський, Ю.К. Бабанський та інші. Теорію та значення діяльнісного підходу розкривають А.С. Виготський, А.М. Леонтьєв, А.Г. Кузнецова, В.С. Маслов. Модель розвитку військової освіти і управлінської культури офіцера та самі педагогічні умови грунтовно подаються в працях М.І. Нещадима, О.А. Прохорова, А.О. Кучерявого, О.М. Маслія, І.В. Толока, Р.В. Торчевського та багатьох інших. 
Мета статті полягає в обгрунтуванні педагогічних умов формування управлінської культури майбутніх офіцерів в процесі практичної підготовки.

Методи дослідження. Дослідження побудоване на загальнонаукових принципах об'єктивності та науковості, що дозволило розкрити специфіку практичної підготовки курсантів ВВНЗ та умов формування управлінської культури майбутніх офіцерів в процесі практичної підготовки. Загальнонаукову орієнтацію дослідження склали основоположні концепції та принципи педагогіки, філософські ідеї у відношенні освіти та виховання, методологічні основи педагогічного дослідження.

Виклад основного матеріалу. Формування управлінської культури в процесі професійної підготовки офіцерів тактичного рівня передбачає підготовку всебічно розвинених, кваліфікованих конкурентоздатних військових фахівців, здатних виконувати типові службові обов'язки відповідно до займаної посади за військовою спеціальністю.

B.I. Загвязінський [4], що займався дослідженням рушійних сил навчального процесу, запропонував ретельніше обгрунтування, розвиток i конкретизацію суперечності, виявленого М.А. Даніловим, сформулювавши основну суперечність навчального процесу як «суперечність між втіленою в діяльності учня досягнутим рівнем знань, розвитку, відношенням до навчання і необхідним рівнем, що знаходиться в найближчій перспективі» [4].

Ю.К. Бабанський, прагнучи визначити якісну своєрідність рушійних сил всього педагогічного процесу в цілому, а не тільки процесу навчання, як основу розглядав суперечність між вимогами пізнавального, практичного, суспільно-корисного характеру, що висувалися, і реальними можливостями їх реалізації [1].

Річ у тому що, виходячи 3 положень діяльнісного підходу (А.М. Леонтьєв), виховання не може здійснюватися поза діяльністю, воно, по суті, і полягає в залученні дитини до відповідної діяльності, в ході якої і відбувається зміна особистості курсанта. Причому, якщо в звичайній діяльності розвиток особи суб'єкта виступає як побічний, супутній продукт, повністю підлеглий безпосередній меті діяльності, то у виховній діяльності результат лежить в площині вирішення протиріччя між ціллю в об'єкті (мета діяльності по «зміні природи людьми») і ціллю в суб'єкті (мета діяльності по «зміні людей людьми»), або в іншому формулюванні - між педагогічними цілями і цілями самих курсантів [7].

На думку А.Г. Кузнецової [5], яка вважає, що після проведення аналізу великого числа робіт із системної проблематики дозволяє стверджувати, що в даний період (до середини 80-х рр.) специфіка соціальних систем реально вивчалася мало і ще менше враховувалася при використанні системного підходу до соціальних об'єктів. Тільки спеціальна робота по узагальненню розрізнених думок, яка не була ніким виконана у той час в Радянському Союзі (та і за кордоном такі роботи з'явилися лише до середини 80-х рр.), 
дозволяє синтезувати характеристики соціальних систем як специфічних об'єктів системного дослідження:

- процеси, що визначають характер всіх структур соціальної системи;

- різноманітних, динамічних відносин соціального явища 3 тими, що детермінують його суспільними макросистемами;

- нерозривну єдність об'єктивного і суб'єктивного;

- складну внутрішню структуру, в якій причинно-наслідковий зв'язок є лише одним з видів взаємозалежності;

- здатність реагувати на процес пізнання, прогнозування i проектування системи;

- вірогідність;

- самоорганізація;

- самоврядування;

- рефлексія;

- ціннісна орієнтованість;

- цілеспрямованість;

- унікальність;

- різноманітність [5].

Тому поступово формувалися специфічні вимоги до соціального пізнання, інструментів системного дослідження соціальних об'єктів. Педагогічний процес, таким чином, є спеціально організованою взаємодією педагогів і вихованців (педагогічна взаємодія або система) з приводу змісту освіти з використанням засобів навчання і виховання (педагогічних засобів) 3 метою вирішення завдань освіти, направлених на задоволення потреб як суспільства, так і самої особи в їі розвитку і саморозвитку.

В психологічній теорії діяльності в рамках теоретичних поглядів А.С. Виготський [3], О.М. Леонтьєв [7] виділяють три основних види людської діяльності - трудову, ігрову й навчальну. Всі ці види тісно взаємозалежні та взаємопов'язані. Значення діяльнісного підходу аргументовано показав в своїх роботах О.М. Леонтьєв. «Для опанування досягненнями людської культури, - писав він, - кожне нове покоління повинне здійснити діяльність, аналогічну (хоча і не тотожню) тій, яка стоїть за цими досягненнями» [7]. Ось чому, щоб підготувати вихованців до самостійного життя i різносторонньої діяльності, необхідно в міру можливостей залучати їх до цих видів діяльності, тобто організовувати повноцінну в соціальному і етичному відношенні життєдіяльність.

Спираючись на дослідження В.С. Маслова [9], можна виділити низку структурних елементів, що характеризують суть соціокультурної підготовки як системи: визначення, усвідомлення і постановка всієї сукупності цілей i завдань соціокультурної підготовки на всіх етапах професійної підготовки офіцера-миротворця; всебічне вивчення й констатація наявного рівня соціокультурної підготовки особи на конкретному етапі життєвого i службового шляху, а також виявлення і врахування основних тенденцій цього розвитку; комплексне і творче використання системи методів, засобів, 
форм i прийомів соціокультурної підготовки, вибір їх оптимального співвідношення 3 урахуванням індивідуальних особливостей офіцера, службових умов його миротворчої діяльності; цілеспрямоване педагогічне спрямування соціокультурного самовиховання слухача-офіцера [9].

На основі результатів теоретичного узагальнення проблеми та проведення факторного аналізу О.А. Прохоров визначає педагогічні умови забезпечення якісної професійної підготовки майбутніх офіцерів, а саме: організаційні (забезпечення відповідної матеріально-технічної бази, укомплектованість педагогічними кадрами відповідного рівня, впровадження нових форм організації навчального процесу, створення професійного середовища через міжсуб'єктну взаємодію із курсантом і потенційним замовником); методичні (вдосконалення науково-методичного забезпечення навчально-виховного процесу, функціонування системи методичної допомоги викладачам); психолого-педагогічні (забезпечення позитивної мотивації навчання, суб'єкт-суб'єктної взаємодії в системі «викладачкурсант»; індивідуалізація і диференціація навчального процесу) [11].

До педагогічних умов розвитку управлінської культури магістрів військового управління Р.В. Торчевський відносить модель розвитку управлінської культури, методику їі розвитку, критерії оцінки ії розвиненості [12].

M.I. Нещадим відмічає особливість широкого застосування в системі навчального процесу ВВНЗ методів співпраці, діалогічної взаємодії, дослідження, проектування, моделювання, проблемного навчання; інформаційні комп'ютерні технології; планування, жорсткий контроль за навчальною діяльністю [10].

За дослідженням М.I. Нещадима, деякі автори ототожнюють ефективність з продуктивністю або результативністю діяльності, інші розглядають iї з результативно-витратного погляду [10, с. 552-553].

В своєму науковому пошуку O.М. Маслій переконливо доводить, що організаційно-педагогічні умови формування офіцера як фахівця - це такі обставини і способи управління й організації їх підготовки у ВВНЗ, що спрямовують розвиток професійно важливих для означеної сфери якостей особистості на поставлену мету i, відтак, спонукають до розвитку загальної здатності встановлювати на основі системного комплексу професійних знань, умінь, досвіду, ціннісних характеристик і професійно важливих у цій сфері особистісних якостей причинно-наслідкові зв'язки та адекватно впливати на процес виконання функцій і завдань в означеній сфері військової діяльності [8].

Як ми бачимо із вище проведеного аналізу наукових пошуків, більшість авторів стверджують, що педагогічні умови в освітньому процесі ВВНЗ $є$ обов'язковою складовою професійного формування управлінської культури офіцера ЗСУ.

Стійкі міжпредметні взаємозв'язки і забезпечення усталеної взаємодії відповідних навчальних дисциплін нададуть можливість утворити 
інтегрований курс 3 управлінської культури, який в подальшому може виступити базою для формування нормативної i навчально-методичної документації для забезпечення процесу формування управлінської культури офіцера.

Ми особливу увагу звертаємо на вертикальні і горизонтальні, внутрішні і зовнішні взаємозв'язки навчальних дисциплін.

Горизонтальні міжпредметні зв'язки утворюються між дисциплінами, які мають спільні змістові лінії і вивчаються одночасно або 3 невеликим розривом у часі в межах одного семестру чи курсу навчання. Вони можуть існувати як достатньо наочно, так i y прихованому вигляді. Такі міжпредметні зв'язки розкриваються на заняттях чи навіть штучно створюються всіма викладачами взаємопов'язаних навчальних дисциплін. Найбільш повно такі зв'язки актуалізуються під час проведення комплексних контрольних заходів, іспитів.

Якщо розглядати процес формування управлінської культури офіцера як логістичну систему, то горизонтальній інтеграції підлягають ті їі компоненти (навчальні дисципліни, що мають спільні змістові лінії, та відповідні їм засоби діагностики якості підготовки), які належать до одного ієрархічного рівня - курсу або семестру навчання. Тому горизонтальна інтеграція $\epsilon$ важливим елементом і системи моніторингу якості управлінської підготовки майбутніх офіцерів [14].

Вертикальними міжпредметними зв'язками ми вважаємо ті зв'язки, що існують наочно - спільні змістові лінії зі спільними термінами і поняттями, тобто з повтореннями, або, здебільшого, у прихованому вигляді - спільні змістові лінії, які відрізняються формою подання термінів і понять та нібито не мають повторень, однак не відрізняються сутністю цих понять.

Такі міжпредметні зв’язки відзначаються викладачами навчальних дисциплін нижчого ієрархічного рівня (семестру, курсу навчання) або навіть зовнішнього педагогічного середовища для даної логістичної системи управлінської підготовки майбутніх офіцерів.

Ми вважаємо, що вертикальна інтеграція також є елементом системи моніторингу якості підготовки формування управлінської культури офіцерів, але вплив на неї зовнішнього педагогічного середовища робить іiі більш невизначеною для оцінювання.

Внутрішні міжпредметні зв’язки утворюються між дисциплінами, що викладаються тільки у внутрішньому педагогічному середовищі, тобто в різних навчальних підрозділах ВВНЗ.

Зовнішні міжпредметні зв'язки - це зв'язки, які стосуються якимось чином зовнішнього педагогічного середовища.

Відтак, зовнішні міжпредметні зв'язки утворюють між дисциплінами, що викладаються у ВВНЗ, і навчальним матеріалом, які курсанти засвоюють у зовнішньому військово-педагогічному середовищі: під час початкової загальновійськової підготовки, практики в установах малого і середнього бізнесу, військового стажування за фахом тощо. 
За В.П. Беспальком, педагогічна технологія розглядається як проект визначеної педагогічної системи, що реалізується на практиці [2].

А.О. Кучерявий відмічає, що молода людина хоче і може служити державі та суспільству, якщо вона патріотична, любить свою національну культуру, поважає працю представників своєї професії. Неможливе успішне служіння без якісної фізичної підготовки людини, ії готовності до виконання професійних завдань, здатності гідно нести звання офіцера в принципі, тому, що в основу проектування виховної роботи повинна бути закладена саме парадигма служіння. I формування особистості майбутнього офіцера має відбуватися з позицій його підготовки до служіння [6].

Організаційно-методичні педагогічні умови формування управлінської культури майбутніх офіцерів - це заходи освітнього процесу, які забезпечують суб'єктну поведінку курсантів, створюють сприятливі умови для них як повноцінного суб'єкта освітнього процесу. Методичноорганізаційні умови освітнього процесу ВВНЗ - це застосування професійно орієнтованих методик i дидактичних технологій проведення навчальних заходів, які мають методично обгрунтовано стимулювати розвиток i вдосконалення процесів мислення із урахуванням вікових особливостей, військово-професійного та управлінського досвіду, майбутніх кар'єрних перспектив і посадових компетенцій майбутніх офіцерів; забезпечення розвитку основ управлінської культури курсантів у освітній діяльності [6; $11]$.

Під організаційно-педагогічними умовами вважаються фактори, які забезпечують ефективність організації навчального процесу. Формування управлінської культури офіцера було забезпечено впровадженням організаційно-педагогічних умов такого процесу. До організаційнопедагогічних умов відносяться: забезпечення професійної мотивації майбутніх офіцерів; орієнтація підготовки на основі професіо- і психограми офіцера (фрагмент управлінської культури); використання інформаційного середовища навчального закладу; впровадження інтерактивних методів для формування управлінської культури майбутніх офіцерів.

Необхідно звернути увагу на внутрішню мотивацію, оскільки вона $є$ залежною від зовнішньої мотивації i особистих управлінських рис майбутнього офіцера. Одним із ефективних способів формування внутрішньої мотивації курсанта може бути актуалізація позитивного досвіду для успішного розв'язання різноманітних завдань, вирішення різних проблем. Позитивний досвід може бути як власним, так і опосередкованим через сприйняття інформації з різноманітних джерел, серед яких - художні твори, засоби масової інформації, науково-популярні й науково-методичні видання, спостереження за успішною роботою викладача, більш досвідчених колег [12].

Управлінська підготовка в професії майбутніх офіцерів виконує одночасно перетворюючу та управляючу функції. Зміст управлінської підготовки майбутніх офіцерів у ВВНЗ може розглядатися як єдність знань, 
навичок та вмінь, досвіду творчої управлінської діяльності військового командира і емоційно-ціннісних відношень у військовій дійсності. Взаємодія цих складових не протирічить їх лінійності [13].

Дидактичні здібності - це здібності передавати курсантам навчальний матеріал доступно, зрозуміло, викликати активну самостійну думку, організовувати самостійну діяльність студентів, керувати пізнавальною активністю. В основі цих здібностей лежить постійна установка на врахування психології курсантів, рівня їх розвитку, можливостей тощо. Конкретно ці здібності проявляються у процесі використання методів передачі знань, організації опанування знань, навичок та умінь, забезпеченні розвитку особистості, перевірці, контролю, оцінюванні результатів навчання.

Академічні здібності - здібності до галузі науки, що $є$ предметом викладання. Здібний викладач добре знає навчальний предмет, досконало, глибоко володіє матеріалом, має до нього великий пізнавальний інтерес, проводить науково-дослідницьку та методичну роботу. Він постійно знайомиться 3 новими досягненнями у своїй галузі, а також у суміжних науках.

Перцептивні здібності - це здібності проникати у внутрішній світ вихованця, психологічна спостережливість, пов'язана 3 розумінням особистості курсанта і його тимчасових психічних станів.

Мовні здібності - це здібності чітко висловлювати свої думки й почуття за допомогою мови, а також $з$ допомогою невербальних засобів (міміки, пантоміміки).

Організаторські здібності - це вміння організовувати аудиторію, згуртовувати i, правильно організовувати власну діяльність (планування, контроль тощо).

Інформаційна педагогічна умова грунтується на використанні управлінської інформатизації в галузі професійної діяльності військового. Інформатизація у військовій галузі визначає необхідність підвищення ефективності військової управлінської підготовки майбутніх офіцерів для зростання професійного i творчого становлення, підготовки i діяльності військового фахівця.

Необхідність створення інформаційного середовища в навчальному закладі пояснюється низкою причин: інформатизація військової освіти, інформаційна культура, яка є складовою управлінської культури майбутнього офіцера.

Також педагогічні умови грунтуються на застосуванні інтерактивних методів навчання. Інтерактивні методи навчання передбачають суттєві зміни методики підготовки офіцерів. Навчальний процес стає більш активним i продуктивним. Інтерактивне навчання передбачає використання таких методів навчання: рольові і ділові ігри, «мозкова атака», круглий стіл, тренінги, метод проектів, використання професійних ситуацій. Ці методи ефективно сприяють формуванню професійних умінь і навичок, створюють атмосферу співробітництва, забезпечують мотивацію навчального процесу. 
Висновки та перспективи подальших досліджень. До організаційнопедагогічних умов формування управлінської культури майбутніх офіцерів необхідно віднести створення професійно орієнтованого навчального середовища у ВВН3; обгрунтування змісту навчальної експериментальної дисципліни змісту «Основи управлінської культури», де враховано цілі, завдання, принципи та специфіку сформованої управлінської культури офіцера; забезпечення міжпредметних зв'язків між навчальними дисциплінами, які створюють сприятливі організаційні та педагогічні умови для цілеспрямованого розвитку управлінської культури майбутніх офіцерів.

Майбутній офіцер в процесі навчання у ВВНЗ повинен оволодіти загальнотеоретичними основами дисциплін, які необхідні для їх управлінської підготовки, науково-методичними та організаційнопедагогічними уміннями.

\section{ЛІТЕРАТУРА}

1. Бабанский Ю.К. Оптимизация процесса обучения: общедидактический аспект. М.: Педагогика, 1977. - 254 с.

2.Беспалько В.П. Педагогика и прогрессивные технологии обучения / В.П. Беспалько. - М. : Ин-т ПО М-ва образования России, 1995. - 208 с.

3.Выготский Л.С. Педагогическая психология / Л.С. Выготский; ред.В.В. Давыдова. - М.: Педагогика, 1994. - 479 с.

4. Загвязинский В.И. Теория обучения: современная интерпретация: учеб. пособие для студ. высш. пед. учеб. заведений / В.И. Загвязинский; под ред. В.А. Сластенина. - М.: Академия, 2001. - $384 \mathrm{c.}$

5. Кузнецова А.Г. Развитие методологии системного подхода в отечественной педагогике: Монография /А.Г. Кузнецова//. - Хабаровск: Изд-во: ХК ИППК ПК, 2001. $152 \mathrm{c}$.

6. Кучерявий А.О. Служіння офіцера як чинник проектування виховної роботи у навчальних закладах військового типу /А.О. Кучерявий // Вісник Черкаського університету: педагогічні науки. - Вип. №14, 2016 р. - С. 53-60.

7. Леонтьев А.Н. Деятельность, сознание, личность / А.Н. Леонтьев. - М.: Политиздат, 1977. - 304 с.

8. Маслій О.М. Формування фахової компетентності майбутніх офіцерів тилу у сфері військово-економічної логістики: автореф. дис. на здобуття наук. ступеня канд. пед. наук: спец. 13.00 .04 «Теорія і методика професійної освіти» / О.М. Маслій. Хмельницький, 2011. - 20, [1] с.

9. Маслов В.С. Теорія і практика культурологічної підготовки слухачів і курсантів: Монографія. - К.: Логос, 1997. - 174 с.

10. Нещадим М.І. Військова освіта України: історія, теорія, методологія, практика: Монографія / М.І Нещадим. - К., 2003. - 766 с.

11.Прохоров О. А. Експериментальна перевірка педагогічних умов та технології готовності майбутніх офіцерів до професійної діяльності на засадах педагогічного менеджменту / О.А. Прохоров // Збірник наукових праць Військового інституту Київського національного університету імені Тараса Шевченка. - К.: ВІКНУ, 2010. - Вип. № 27. - С.322- 332 .

12. Торчевський Р.В. Модель розвитку управлінської культури майбутніх магістрів військового управління в системі післядипломної освіти /Р.В.Торчевський// Вісник Національного університету оборони України. - 2012. - Вип. 3(28). - С.124-129.

13. Ягупов В.В. Військова дидактика: Навчальний посібник. - К.: Видавничопліграфіний центр «Київський університет». 2000. - 400с. 
14. Ягупов В. В. Методика навчання студентів спілкуванню в управлінській діяльності: навч. посіб / В.В. Ягупов, Н.М. Костриця, В.І. Свистун. - К.: Центр навч. літератури, 2009. - 272 с.

\section{REFERENCES}

1. Babanskiy, Yu.K. (1977). Optimizatsiya protsessa obucheniya: obschedidakticheskiy aspekt [Optimization of the education process: a common didactic aspect]. - M.: Pedagogika, 254. (in Russian).

2. Bespalko, V.P. (1995). Pedagogika i progressivnyie tehnologii obucheniya [Pedagogy and progressive learning technologies]. - M. : In-t PO M-va obrazovaniya Rossii, 208. (in Russian).

3. Vyigotskiy, L.S. (1994). Pedagogicheskaya psihologiya [Pedagogical psychology]. - M. : Pedagogika, 479. (in Russian).

4. Zagvyazinskiy, V.I. (2001). Teoriya obucheniya: sovremennaya interpretatsiya: ucheb. posobie dlya stud. vyissh. ped. ucheb. zavedeniy [A learning theory: modern interpretation]. M. : Akademiya, 384. (in Russian).

5. Kuznetsova, A.G. (2001). Razvitie metodologii sistemnogo podhoda v otechestvennoy pedagogike [Development of the methodology of system-based approach in national pedagogy]: Monografiya. - Habarovsk: Izd-vo: HK IPPK PK, 152. (in Russian).

6. Kucheryaviy A.O. (2016). Sluzhinnya ofitsera yak chinnik proektuvannya vihovnoyi roboti u navchalnih zakladah viyskovogo tipu [Officer's service as a factor of developing educational work in military educational institutions] // Visnik Cherkaskogo universitetu: pedagogichni nauki. - Vip. no. 14, P. 53-60. (in Ukrainian).

7. Leontev, A.N. (1977). Deyatelnost, soznanie, lichnost [Activity, consciousness, personality]. - M. : Politizdat, 304. (in Russian).

8. Maslij, O.M. (2011). Formuvannja fahovoi' kompetentnosti majbutnih oficeriv tylu u sferi vijs'kovo-ekonomichnoi' logistyky [Formation of professional competence of future logistics officers in the area of military-economic logistics]. Extended abstract of candidate's thesis. Hmel'nyc'kyj, 20 s. (in Ukrainian).

9. Maslov, V.S. (1997). Teorija i praktyka kul'turologichnoi' pidgotovky sluhachiv i kursantiv [Theory and practice of culturological training of officer students and cadets]. Kyi'v: Logos, 174. (in Ukrainian).

10. Neshhadym, M.I. (2003). Vijs'kova osvita Ukrai'ny: istorija, teorija, metodologija, praktyka [Military education of Ukraine: history, theory, methodology, practice]. Kyi'v, 766. (in Ukrainian).

11. Prohorov, O.A. (2010). Eksperymental'na perevirka pedagogichnyh umov ta tehnologii' gotovnosti majbutnih oficeriv do profesijnoi' dijal'nosti na zasadah pedagogichnogo menedzhmentu [Experimental verification of pedagogical conditions and technology of future officers' readiness for professional activity on the basis of pedagogical management]. Zbirnyk naukovyh prac' Vijs'kovogo instytutu Kyi'vs'kogo nacional'nogo universytetu imeni Tarasa Shevchenka. Kyi'v: VIKNU, no. 27, P. 322- 332. (in Ukrainian).

12. Torchevs'kyj, R.V. (2012). Model' rozvytku upravlins'koi' kul'tury majbutnih magistriv vijs'kovogo upravlinnja $\mathrm{v}$ systemi pisljadyplomnoi' osvity [Model of developing management culture of future masters of military management in the postgraduate education system]. Visnyk Nacional'nogo universytetu oborony Ukrai'ny. Kyi'v, no. 3(28), P. 124-129. (in Ukrainian).

13. Jagupov V.V. (2000). Vijs'kova dydaktyka [Military didactics]. Kyi'v: Kyi'vs'kyj universytet, 400. (in Ukrainian).

14. Jagupov, V.V., Kostrycja N.M., Svystun V.I. (2009). Metodyka navchannja studentiv spilkuvannju $\mathrm{v}$ upravlins'kij dijal'nosti [Communication teaching techniques in management activities]: navch. posibn. Kyi'v: Centr navch. literatury, 272. (in Ukrainian). 


\section{РЕЗЮМЕ}

Сергей Бурый,

Военный институт Киевского национального университета имени Тараса Шевченка

\section{Педагогические условия формирования управленческой культуры у будущих офицеров в процессе практической подготовки}

В статье рассмотрены научные исследования по теории значения движущих сил и деятельностного прочесса в системе образования и их практическое значение при формировании знаний, навыков и умений в управленческой культуре офицера. Раскрываются и научно обосновываются педагогические условия, определяюшие обеспечение качественной профессиональной подготовки будущих офицеров, а именно: организачионные, методические, психолого-педагогические. Теоретически обосновываются управленческая культура офицера и ее практическое значение для офицера при исполнении им сочииально значимых профессиональных обязанностей.

Ключевые слова: управленческая культура офичера; педагогические условия; управленческая подготовка в высшем военном учебном заведении.

\section{SUMMARY}

Serhii Buryi

Military Institute of Taras Shevchenko National University of Kyiv

\section{Pedagogical conditions of formation of management culture for future officers in the practical training process}

Introduction. Development of pedagogical conditions shaping management culture during professional training of future officers. Scientific and practical analysis of literary sources regarding theoretical and practical significance of pedagogical conditions for the educational process development at higher military educational institutions ("HMEI") in accordance with the world standards of servicemen's training.

Purpose is to substantiate pedagogical conditions shaping management culture of future officers during the practical training process.

Methods. The research is based on general scientific principles of objectivity and scientific knowledge, which allowed uncovering the specifics of practical training for HMEI cadets and conditions shaping management culture of future officers in the practical training process. Basic concepts and principles of pedagogy, philosophical ideas in education and personal development, and methodological foundations of pedagogical research were the general scientific focus of the research.

Results. Justified theory of role learning with due respect to peculiarities of the educational process in a military educational institution.

Conclusions. Organizational and pedagogical conditions of management culture of future officers forming should include establishment of a professionally oriented educational environment at a HMEI; rationale for the content of the experimental academic discipline Fundamentals of Management Culture that considers goals, tasks, principles and specifics of the shaped management culture of officers. It should include also ensuring interdisciplinary relationships between academic disciplines that create favorable organizational and pedagogical conditions for the purposeful development of future officers' management culture.

Key words: administrative culture of an officer; pedagogical conditions; management training at the higher military educational institution 